УДК 93/94

DOI 10.22162/2500-1523-2019-1-48-65

\title{
Калмыцкая автономная область в составе Ставропольского края в 1957 - первой половине 1958 гг.: особенности политико-правового статуса
}

Kalmyk Autonomous Oblast as a Territory within Stavropol Krai in 1957 and early-to-mid 1958: Peculiarities of the Political and Legal Status

\section{Евгений Александрович Гунаев (E. Gunaev) ${ }^{l}$}

\author{
${ }^{1}$ Калмыцкий научный центр РАН (д. 8, ул. им. И. К. Илишкина, 358000 Элиста, \\ Российская Федерация) \\ кандидат юридических наук, старший научный сотрудник, \\ ORCID: 0000-0002-7173-4170. E-mail: gunaevea@kigiran.com
}

Kalmyk Scientific Center of the RAS (8, Ilishkin Str., Elista 358000, Russian Federa tion)

Cand. Sc. (Law), Senior Research Associate

ORCID: 0000-0002-7173-4170. E-mail: gunaevea@kigiran.com

Аннотация. Статья посвящена особенностям политико-правового статуса Калмыцкой автономной области как субъекта РСФСР в составе Ставропольского края (1957-1958 гг.) после восстановления её автономии. На основе историкоправового метода исследования рассмотрены положения советских конституций соответствующего периода, нормативные акты высших органов государственной власти СССР и РСФСР. Также проанализированы взгляды советских ученых-государствоведов на федеративную природу РСФСР, место автономных областей в «иерархии» советских автономий, особенности регулирования их правового положения в указанный период. Учитывая кратковременность существования автономной области, автор приходит к характеристике автономии Калмыкии данного периода как переходной формы к возвращению прежнего статуса автономной республики.

Ключевые слова: РСФСР, Калмыцкая автономная область, Ставропольский край, восстановление автономии репрессированных народов, политико-правовой статус

Благодарности. Исследование проведено в рамках государственной субсидии - проект «Комплексное исследование процессов общественно-политического и культурного развития народов Юга России» (№ госрегистрации: АААA-А19-119011490038-5).

Для цитирования: Гунаев Е. А. Калмыцкая автономная область в составе Ставропольского края в 1957 - первой половине 1958 гг.: особенности полити- 
ко-правового статуса. Монголоведение. 2019;(1):48-65. DOI 10.22162/2500-15232019-1-48-65.

Abstract. The article deals with peculiarities of the political and legal status of Kalmyk Autonomous Oblast as a federal subject of the RSFSR within Stavropol Krai (1957-1958) after the restoration of autonomy. The study applies historical and legal research methods to examine provisions of respective Soviet constitutions, statutory acts issued by the supreme governing institutions of the USSR and RSFSR. It also analyzes views of Soviet political scientists on the federal nature of the RSFSR, the place of autonomous regions in the 'hierarchy' of Soviet autonomies, peculiarities pertaining to the regulation of their legal status during the specified period.

Given that the Autonomous Oblast proved shot-lived enough, the paper characterizes Kalmykia's autonomy of that period as a transitional form towards the former status of Autonomous Republic.

Keywords: RSFSR, Kalmyk Autonomous Oblast, Stavropol Krai, restoration of repressed peoples' autonomies, political and legal status

Acknowledgments: Research was performed within a government subsidy - project 'Socio-Political and Cultural Development of South Russia's Peoples: a Comprehensive Research of Respective Processes' (State Reg. No. AAAA-A19-119011490038-5).

For citation: Gunaev E. Kalmyk Autonomous Oblast as a Territory within Stavropol Krai in 1957 and early-to-mid 1958: Peculiarities of the Political and Legal Status. Mongolian Studies. 2019;(1):48-65. DOI 10.22162/2500-1523-2019-1-48-65.

\section{Введение}

В конце 1950-х гг. в СССР были восстановлены отдельные автономии народов, подвергшихся депортации в годы Великой Отечественной войны. Среди них была и Калмыцкая автономная область, образованная в составе Ставропольского края в 1957 г. и просуществовавшая 1,5 года до своего преобразования в Калмыцкую АССР.

Данному периоду в истории Калмыкии посвящен ряд работ, в основном они рассматривают происходившие процессы с исторической точки зрения, используя историко-генетический, хронологический и системный методы исследования [Белоусов 2012; 2013; Запариванный 2005; 2006; 2011; Илюмжинов, Максимов 1998; История 2009; Максимов 2013; 2017; Судавцов 2010; Убушаев и др. 2007; 2009; Убушаев 2017а; 2017б; и др.].

Отдельно выделим научную статью X. И. Тугуза, однако в ней затронуты политико-правовые аспекты процесса реабилитации 
калмыцкого народа [Тугуз 2006], что не является предметом исследования настоящей работы.

\section{Постановка задачи}

Цель настоящей статьи - исследовать политико-правовой статус Калмыкии в форме автономной области в указанный период с позиции действовавшего в то время советского законодательства и научной доктрины.

Как известно, в советской науке государственного права не было единой точки зрения на то, какие автономные единицы считать субъектами РСФСР.

В особенности это касалось автономных областей, так как они входили в состав краев, что обуславливало специфику их статуса. В связи с этим необходимо:

- изучить хронологическую последовательность юридических актов в отношении восстановления автономии Калмыкии как автономной территориальной единицы в составе РСФСР;

- рассмотреть взгляды ученых-государствоведов советского периода на правовую природу автономной области периода 1950-х гг.

\section{Основная часть}

Восстановлению автономий репрессированных народов в форме указов и законов высших органов государственной власти СССР и РСФСР предшествовало постановление президиума ЦК КПСС «О восстановлении национальной автономии калмыцкого, карачаевского, балкарского, чеченского и ингушского народов» 24 ноября 1956 г., которым утверждались соответствующие проекты указов президиума Верховного Совета СССР. В частности, устанавливалось: «Образовать на территории бывшей Калмыцкой АССР Калмыцкую автономную область, включив ее в состав Ставропольского края РСФСР» [Реабилитация 2003: 201].

9 января 1957 г. принимается указ президиума Верховного Совета СССР «Об образовании Калмыцкой автономной области в составе РСФСР», в котором было признано необходимым «в целях создания необходимых условий для национального развития» восстановить национальную автономию калмыцкого народа. Президиуму Верховного Совета РСФСР было рекомендовано рас- 
смотреть вопрос об образовании Калмыцкой автономной области в составе Ставропольского края РСФСР; установить границы и административно-территориальное устройство Калмыцкой автономной области; утвердить Организационный комитет Калмыцкой автономной области, на который возложить, впредь до выборов областного Совета, руководство хозяйственным и культурным строительством на территории автономной области.

Утратившими силу стали считаться: указ Президиума Верховного Совета СССР от 27 декабря 1943 г. «О ликвидации Калмыцкой АССР и образовании Астраханской области в составе РСФСР», за исключением статьи 2, предусматривающей образование в составе РСФСР Астраханской области, и статья 2 указа Президиума Верховного Совета СССР от 17 марта 1956 г. в части запрещения калмыкам возвращаться на прежнее местожительство [Книга памяти 2004: 69-70].

Далее были приняты:

- указ Президиума Верховного Совета РСФСР от 9 января 1957 г. «Об образовании Калмыцкой автономной области в составе Ставропольского края» [Книга памяти 2004: 70];

- указ Президиума Верховного Совета РСФСР от 9 января 1957 г. «Об утверждении Организационного комитета по Калмыцкой автономной области Ставропольского края» [Книга памяти 2004: 71];

- указ Президиума Верховного Совета РСФСР от 12 января 1957 г. «Об административно-территориальном составе Калмыцкой автономной области Ставропольского края» [Книга памяти 2004: 71-72].

Законом СССР от 11 февраля 1957 г. «Об утверждении Указов Президиума Верховного Совета СССР о восстановлении национальной автономии балкарского, чеченского, ингушского, калмыцкого и карачаевского народов» в статью 22 Конституции СССР 1936 г. о территориальном составе РСФСР были внесены соответствующие изменения, где среди автономных областей была указана Калмыцкая [Закон СССР 1957а].

В историографии Калмыкии приведены следующие точки зрения: 
- «восстанавливалась государственность калмыцкого народа в существовавшей до октября 1935 г. форме — в качестве субъекта РСФСР, но в составе Ставропольского края» [Илюмжинов, Максимов 1998: 109];

- «автономия советской Калмыкии восстанавливалась с понижением статуса как автономная область в составе Ставропольского края» [Убушаев и др. 2007: 404-405; Запариванный 2011: 229].

22 июня 1958 г. Калмыцкая автономная область, образованная в 1957 г. в составе Ставропольского края, была преобразована в Калмыцкую АССР [История 1970: 129]. Автономные республики согласно Конституциям СССР 1936 г. и РСФСР 1937 г. непосредственно находились в составе РСФСР, не входя в состав краев или областей [Советские конституции 2015: 16, 25].

Указом Президиума Верховного Совета СССР от 29 июля 1958 г. было утверждено произведенное Указом Президиума Верховного Совета РСФСР от 26 июля 1958 г. преобразование Калмыцкой автономной области в Калмыцкую Автономную Советскую Социалистическую Республику [Книга памяти 2004: 296297].

Законом СССР от 25 декабря 1958 г. «Об утверждении Указов Президиума Верховного Совета СССР „О переименовании Бурят-Монгольской Автономной Советской Социалистической Республики“ и „О преобразовании Калмыцкой автономной области в Калмыцкую Автономную Советскую Социалистическую Республику“ и о внесении изменений в статью 22 Конституции (Основного Закона) СССР» в составе РСФСР была указана Калмыцкая АССР [Закон СССР 1958]. Затем соответствующие изменения были внесены Законом РСФСР от 27 декабря 1958 г. в статьи 14 и 31 Конституции (Основного Закона) РСФСР 1937 г. [Закон РСФСР 1958].

Рассмотрим взгляды советских государствоведов на правовую природу автономной области в РСФСР периода конца 1950-х гг.

Н. Я. Куприц считал, что автономная область как форма советской автономии обладала не законодательной, а административной автономией. «Автономная область — не государство, не республика, — это национальная область союзной республики, ко- 
торая по ряду объективных оснований в настоящий исторический момент не может быть отнесена к числу автономных республик» [Куприц 1940:19].

Согласно Т. Б. Анисимовой, Российская Федерация сразу же с момента своего образования стала развиваться как федерация автономных образований. Ее субъектами стали не только автономные республики - высшая форма советской автономии, но и автономные области, ранее национальные, ныне автономные округа. Вместе с тем она обращает внимание на тот факт, что по Конституции РСФСР 1937 г. автономные республики были представлены в высшем органе государственной власти России - в Президиуме Верховного Совета республики. Автономные области и автономные округа РСФСР не были представлены в высших органах государственной власти своей союзной республики [Анисимова 1983: 29, 34].

Д. Л. Златопольский утверждал, что советская автономия проявляется в двух формах: политической (национальное автономное государство - автономная республика) и административной (национальные государственные образования - автономная область, национальный округ). Если в Конституции РСФСР 1925 г. устанавливались основы правового положения автономной республики и автономной области в специальной главе «Об автономных советских социалистических республиках и областях», то федеративная природа государственного устройства РСФСР не нашла достаточно полного и подробного закрепления в Конституции РСФСР 1937 г. В ней перечислены автономные республики и автономные области, а также содержатся три главы, специально посвященные соответственно высшим органам государственной власти и государственного управления автономных республик, а также органам государственной власти автономных областей [Златопольский 1960: 207-208].

Как обращал внимание Д. Л. Златопольский, несмотря на это в Конституции РСФСР 1937 г. не сформулировано положение о том, какие автономные единицы являются субъектами федерации. Он полагал, что все автономии в составе РСФСР (автономные республики, автономные области, национальные округа) являлись 
ее субъектами, и соответственно наличие в Конституции РСФСР точного указания о субъектах федерации более полно отразило бы федеративный характер РСФСР, а также в законодательной форме установило бы существенную особенность Российской Федерации, основанной на автономии [Златопольский 1960: 208-209].

А. И. Ким считал, что РСФСР, будучи федерацией, не является союзным государством. Он придерживался распространенной точки зрения, согласно которой своеобразие РСФСР как федерации состоит в том, что «ее субъектами являются автономные образования, созданные путем выделения соответствующих территорий в рамках республики и вступившие с последней в отношения внутреннего федерирования» [Ким 1960: 27].

Как отмечал А. И. Ким, сторонники данной точки зрения расходились лишь в вопросе о круге субъектов федерации. Часть из них считала, что круг субъектов РСФСР исчерпывается автономными республиками, другие - что субъектами РСФСР являются АССР и автономные области или же все виды советской автономии, включая национальные округа.

А. М. Халилов, напротив, отрицал, что РСФСР не является союзным государством, поскольку федерация - это и есть союзное государство. Главный признак РСФСР как федеративного государства он видел в том, что ее составные части - автономные республики являются государствами. «Следовательно, автономные области и национальные округа, не являясь государствами, не могут быть субъектами федерации. Субъектом федерации может быть лишь государство...» [Халилов 1967: 74-75].

Он опровергал один из доводов, что автономные области и национальные округа являются субъектами федерации, поскольку они представлены в Совете национальностей Верховного Совета СССР. Согласно А. М. Халилову, фактически этот аргумент не имеет абсолютно никакого отношения к вопросу о субъектах Российской Федерации. «Ведь здесь речь идет о представительстве в органах Союза ССР, а не Российской Федерации. Представительство автономных областей и национальных округов в Верховном Совете СССР говорит о том, что этот орган построен таким образом, чтобы удовлетворять не только общие, но и специфические 
интересы народов СССР, и это нисколько не может характеризовать те или иные автономные единицы как субъекты Российской Федерации» [Халилов 1967: 76].

И. А. Азовкин и В. М. Иезуитов отмечали следующее:

- Конституция СССР 1936 г. и конституции союзных республик сохранили за автономной областью статус автономной национальной административно-территориальной единицы союзной советской социалистической республики и отнесли ее органы к числу местных органов государственной власти (ст. 94 Конституции СССР, ст. 77 Конституции РСФСР);

- закрепили за ней вытекающие из этого обстоятельства дополнительные права. Это нашло свое выражение, прежде всего, в том, что за каждой автономной областью было обеспечено право непосредственно направлять пять своих представителей в Совет национальностей Верховного Совета СССР;

- отнеся Советы депутатов трудящихся автономных областей к числу местных органов государственной власти, конституции союзных республик предусмотрели право Совета депутатов трудящихся автономной области разработать с учетом национальных особенностей Положение об автономной области и представить его на утверждение Верховного Совета союзной республики (ст. 76 Конституции РСФСР 1937 г.) [Азовкин, Иезуитов 1959: 73-74; Советские конституции 2015: 21, 30].

И. А. Азовкин и В. М. Иезуитов приводят примеры гарантий прав автономных областей со стороны Верховного Совета СССР. Так, законом от 11 февраля 1957 г. из Конституции СССР был исключен перечень краев и областей, решение вопросов административно-территориального устройства было передано в ведение союзных республик. Однако перечень автономных областей был сохранен в Конституции СССР. Образование новых автономных областей могло быть произведено лишь с разрешения высших органов власти СССР (п «е» ст. 14 Конституции СССР 1936 г.) [3акон СССР 1957б]. Тем самым, отмечается, территориальные права автономных областей были поставлены под защиту высших органов власти Союза ССР.

Также за депутатами автономных областей в Совете Национальностей СССР было обеспечено право принимать участие в 
работе Экономической комиссии при рассмотрении вопросов, затрагивавших интересы этих областей [Постановление 1957].

За органами государственной власти и управления автономных областей, входящих в состав краевых образований, Конституции СССР и РСФСР сохранили определенную самостоятельность по отношению к краевым органам. Развивая положения Конституции СССР 1936 г., Конституция РСФСР 1937 г., установив общее правило о том, что вышестоящий местный орган государственной власти и управления может отменить акты нижестоящего (ст. 90 и 91), сделала исключение в отношении актов, принимаемых органами автономных областей. Так, согласно ст. 46 отменять решения и распоряжения исполкомов Советов депутатов трудящихся автономных областей, а также приостанавливать решения и распоряжения Советов депутатов трудящихся автономных областей имело право правительство Федерации. Отменять решения и распоряжения Советов депутатов трудящихся этих областей был вправе только Президиум Верховного Совета РСФСР (ст. 33) [Азовкин, Иезуитов 1959: 74; Советские конституции 2015: 27].

Как известно, важным правовым актом, характеризующим права автономной области РСФСР, вошедшей в состав краевого (областного) объединения, и органами краевой (областной) власти было одноименное постановление ВЦИК и СНК РСФСР от 29 октября 1928 г. [Конституции и конституционные акты 1940: 211-213].

В связи с этим, поскольку все автономные области в РСФСР, за исключением Тувинской, входили в состав краев, а также предусмотренные Конституцией СССР Положения об автономных областях еще не были приняты и соответствующее Постановление ВЦИК и СНК РСФСР от 29 октября 1928 г. не было отменено, П. Г. Семенов предлагал сообразовывать всю практику взаимоотношений между краевыми объединениями и входящими в их состав автономными областями [Семенов 1959: 38].

Однако И. А. Азовкин и В. М. Иезуитов отмечали то обстоятельство, что названное постановление ВЦИК и СНК РСФСР от 29 октября 1928 г., закрепившее в свое время широкие правомочия автономных областей в государственном, хозяйственном и куль- 
турном строительстве, хотя формально и не было отменено, фактически прекратило свое действие после принятия Конституции СССР 1936 г. и Конституции РСФСР 1937 г. [Азовкин, Иезуитов 1959: 74-75].

Если рассматривать с точки зрения полномочий регионов РСФСР в области плановой экономики, то в документах того периода учитывались только автономные республики, края, области. Автономные области не указывались, так как находились в составе краев, за исключением Тувинской, которая непосредственно входила в состав РСФСР. В качестве примера можно привести Постановление Совета Министров РСФСР от 29 марта 1958 г. № 310 «О плане использования государственных ресурсов продуктов животноводства по РСФСР на 1958 год» [РСФСР. Законы и постановления 1960: 132-136].

Вместе с тем, если рассматривать конституционные нормы, в частности о территориальном составе РСФСР, то, безусловно, Калмыцкая автономная область являлась субъектом РСФСР, хотя и в составе края. Как показал опыт федеративного развития России, данный факт не является препятствием к статусу «субъекта РСФСР». И в прошлом, и в настоящее время в составе Российской Федерации находятся сложносоставные субъекты.

Если рассматривать вопрос о «понижении» статуса, то это было вызвано объективными причинами, поскольку фактически автономия Калмыкии создавалась «с нуля» и заново в сложных экономических условиях. Учитывая, что Калмыцкая автономная область просуществовала 1,5 года, а затем была преобразована в республику, представляется, что вопрос о понижении статуса не играет особой исторической роли. Другой аспект, если бы Калмыкия сохранилась бы как автономная область в составе Ставропольского края длительное время, скажем 10-15 лет, то тогда это можно было трактовать как отдельный период в истории государственности Калмыкии.

Интересно отметить, что указ Президиума Верховного Совета СССР от 9 января 1957 г. «Об образовании Калмыцкой автономной области в составе РСФСР» формально был отменен только с принятием постановления Верховного Совета СССР от 7 мар- 
та 1991 г. № 2013-1 «Об отмене законодательных актов в связи с Декларацией Верховного Совета СССР от 14 ноября 1989 года „О признании незаконными и преступными репрессивных актов против народов, подвергшихся насильственному переселению, и обеспечении их прав“"». Данным постановлением был отменён ряд актов высших органов государственной власти СССР, однако это не означало «автоматического решения вопросов национально-государственного устройства и административно-территориального деления, возникших вследствие насильственного переселения отдельных народов» [Постановление 1991].

\section{Выводы}

- статус «автономной области» 1957 г. - первой половины 1958 г. для Калмыкии явился переходной формой к возвращению прежнего статуса автономной республики в 1958 г.;

- в связи с этим государственность Калмыкии была полностью восстановлена в прежней форме, которая существовала, начиная с октября 1935 г. по декабрь 1943 г., за исключением территориального состава (территории двух прежних районов остались в составе Астраханской области).

\section{Источники}

Закон РСФСР 1958 - Закон РСФСР от 27 декабря 1958 г. «О внесении изменений в статьи 14 и 31 Конституции (Основного Закона) РСФСР» [электронный ресурс] // URL: http://constitution.garant.ru/history/ussrrsfsr/1937/zakony/3946626/ (дата обращения: 20.02.2019).

Закон СССР 1957а - Закон СССР от 11 февраля 1957 г. «Об утверждении Указов Президиума Верховного Совета СССР о восстановлении национальной автономии балкарского, чеченского, ингушского, калмыцкого и карачаевского народов» // Ведомости Верховного Совета СССР. 1957. № 4. Ст. 78.

Закон СССР 19576 - Закон СССР от 11 февраля 1957 г. «Об отнесении к ведению союзных республик разрешения вопросов областного, краевого административно-территориального устройства» // Ведомости Верховного Совета СССР. 1957. № 4. Ст. 80.

Закон СССР 1958 - Закон СССР от 25 декабря 1958 г. «Об утверждении Указов Президиума Верховного Совета СССР „О переименовании 
Бурят-Монгольской Автономной Советской Социалистической Республики“ и „О преобразовании Калмыцкой автономной области в Калмыцкую Автономную Советскую Социалистическую Республику“" и о внесении изменений в статью 22 Конституции (Основного Закона) СССР» // Ведомости Верховного Совета СССР. 1959. № 1. Ст. 18.

Конституции и конституционные акты 1940 - Конституции и конституционные акты РСФСР. 1918-1937 гг.: сб. док-тов под общ. ред. ак. А. Я. Вышинского / АН СССР. Ин-т права. М.: Ведомости Верховного Совета СССР. 1940 (299 с.). С. 211-213.

Книга памяти 2004 - Книга памяти ссылки калмыцкого народа. Т. 1, кн. 3: Восстановление автономии и реабилитация калмыцкого народа. ч. 1, Восстановление автономии (1956-1963 гг.): сб. док-тов и мат-лов / [ред. совет: К. Н. Илюмжинов (пред.) и др.; сост.: В. 3. Атуева и др.]. Элиста: Калм. кн. изд-во, 2004. 586 с.

Постановление 1991 - Постановление Верховного Совета СССР от 7 марта 1991 г. № 2013-1 «Об отмене законодательных актов в связи с Декларацией Верховного Совета СССР от 14 ноября 1989 года „О признании незаконными и преступными репрессивных актов против народов, подвергшихся насильственному переселению, и обеспечении их прав“"» // Ведомости Съезда народных депутатов СССР и Верховного Совета СССР. 1991. № 11. Ст. 302.

Постановление 1957 - Постановление Совета Национальностей Верховного Совета СССР «Об образовании Экономической комиссии Совета Национальностей» 11 февраля 1957 г. // Ведомости Верховного Совета СССР. 1957. № 4. Ст. 89.

Реабилитация 2003 - Реабилитация: как это было. Документы Президиума ЦК КПСС и другие материалы. Том II. Февраль 1956 - начало 80-х годов / сост. Артизов А. Н., Сигачев Ю. В., Хлопов В. Г., Шевчук И. Н. М.: МФД, 2003. 960 с.

РСФСР. Законы и постановления 1960 - РСФСР. Законы и постановления. Хронологическое собрание законов, указов Президиума Верховного Совета и постановлений Правительства РСФСР, 1958-1960 / [ред. М. А. Копыловская; сост. и отв. ред. В. А. Болдырев и др.]. В 7 т. Т. 7: 1958-1960 гг. М.: Госюриздат, 1960. 671 с.

Советские конституции 2015 - Советские конституции. Хрестоматия. В 4 частях. Часть 3. СССР, 1936-1977 гг. / сост. Д. В. Кузнецов. Благовещенск: Благовещенский государственный педагогический университет, 2015. 418 с. 


\section{Литература}

Азовкин, Иезуитов 1959 - Азовкин И. А., Иезуитов В. М. Назревшие вопросы правового положения автономной области // Советское государство и право. 1959. № 5. С. 69-78.

Анисимова 1983 - Анисимова Т. Б. Развитие конституционного законодательства РСФСР в области национально-государственного устройства республики // Конституционные основы национально-государственного строительства СССР: Сб. ст. М.: Акад. общ. наук при ЦК КПСС. $1983.131 \mathrm{c}$.

Белоусов 2012 - Белоусов С. С. Административно-территориальные преобразования в Нижнем Поволжье в годы Великой Отечественной войны и их последствия // Народы Юга России в отечественных войнах: мат-лы Междунар. науч. конф. (6-7 сентября 2012 г., Ростов-наДону) / отв. ред. акад. Г. Г. Матишов. Ростов н/Д: Изд-во ЮНЦ РАН, 2012. 480 c. (С. 290-295).

Белоусов 2013 - Белоусов С. С. Роль этнического фактора в формировании административных границ национально-территориальных образований калмыцкого народа в XIX - первой половине XX вв. // Межэтнический и межконфессиональный диалог как консолидирующая основа общества в борьбе против глобальных угроз терроризма и экстремизма: мат-лы Междунар. науч.-практ. еонф. (г. Астрахань, 10 октября 2013 г.) / сост. и отв. ред. А. В. Сызранов, О. С. Попова. Астрахань: Издатель Сорокин Р. В., 2013. 180 с. (С. 102-110).

Запариванный 2006 - Запариванный Р. И. Восстановление национальной автономии калмыцкого народа 1953-1958 гг.: автореферат дис. ... канд. ист. наук. Астрахань, 2006. 22 с.

Запариванный 2005 - Запариванный Р. И. Образование Калмыцкой автономной области в составе Ставропольского края // Вклад народов Северного Кавказа в победу над фашизмом в Великой Отечественной войне 1941-1945 гг.: мат-лы Межрегион. науч.-практ. конф. (2728 апреля, 2005 г.) / [редкол.: Убушаев В. Б. (отв. ред.) и др.]. Элиста: Калмыц. гос. ун-т, 2005. 204 с. (С. 191-192).

Запариванный 2011 - Запариванный Р. И. Переход Калмыцкой автономной области в статус национальной республики (1957-1958) // Гуманитарные исследования. 2011. № 1. С. 229-232.

Златопольский 1960 - Златопольский Д. Л. Государственное устройство СССР. М.: Госюриздат, 1960. 300 с.

Илюмжинов, Максимов 1998 - Илюмжинов К. Н., Максимов К. Н. На пути к демократии. Элиста: АПП «Джангар», 1998. 288 с. 
История 2009 - История Калмыкии с древнейших времен до наших дней. В 3 т. Т. ІІ. Элиста: Герел, 2009.

История 1970 - История национально-государственного строительства в СССР [1917-1966 гг.] / отв. ред. Д. А. Чугаев; АН СССР. Ин-т истории. М.: Мысль, 1968-1970. В 2 т. Т. 2: Национально-государственное строительство в СССР в период социализма и строительства коммунизма. (1937-1967 гг.). 1970. 276 с.

Ким 1960 - Ким А. И. К вопросу о государственно-правовой природе РСФСР // Известия вузов. Правоведение. 1960. № 1. С. 26-33.

Куприц $1940-$ Куприц Н. Я. Об автономной области, как одной из форм советской автономии, и ее правовом положении // Советское государство и право. 1940. № 5-6. С. 11-23.

Максимов 2013 - Максимов К. Н. Калмыкия в советскую эпоху: политика и реалии. Элиста: АУ РК «Издательский Дом «Герел», 2013. 464 с. Максимов 2017 - Максимов К. Н. От «хрущевской оттепели» к политической реабилитации: восстановление автономии калмыцкого народа // Вестник Калмыцкого института гуманитарных исследоваий РАН. 2017. № 1. С. 38-47.

Семенов 1959 - Семенов П. Г. Автономия в советском государственном строительстве // Советское государство и право. 1959. № 3. С. 30-40. Судавцов $2010-$ Судавиов Н. Д. Калмыкия в составе Ставропольского края в период восстановления автономии калмыцкого народа (19571958 гг.) // Вестник Калмыцкого института гуманитарных исследований РАН. 2010. № 2. С. 15-20.

Тугуз 2006 - Тугуз $X$. И. Ликвидация и восстановление национальной государственности калмыков: политико-правовой аспект // Вестник Адыгейского государственного университета. 2006. № 4. С. 82-94.

Убушаев и др. 2007 - Убушаев В. Б., Убушаев К. В. Калмыки: выселение, возвращение, возрождение. 1943-1959 гг. / Федеральное агентство по образованию, Калмыцкий гос. ун-т. Элиста: Изд-во Калмыцкого ун-та, 2007. 494 с.

Убушаев и др. 2009 - Убушаев В. Б., Убушаев К. В. Калмыки в конце 50-х годов XX века: от автономной области к автономной республике // Вестник Регионального института инновационных исследований. 2009. № 1. C. 10-15.

Убушаев 2017а - Убушаев К. В. Возрождение национальной автономии репрессированного народа 1957-1958 гг. / Министерство образования и науки РФ, Калмыцкий государственный университет имени Б. Б. Городовикова. Элиста: Изд-во Калм. ун-та, 2017. 118 с. 
Убушаев 2017б - Убушаев К. В. Восстановление национальной автономии калмыцкого народа в составе РСФСР // Вестник Калмыцкого университета. 2017. № 1 (33). С. 68-73.

Халилов 1967 - Халилов А. М. РСФСР - социалистическое федеративное государство. Казань: Изд-во Казанского ун-та, 1967. 138 с.

\section{Sources}

Zakon RSFSR ot 27 dekabrya 1958 g. «O vnesenii izmeneniy v stat'i 14 i 31 Konstitutsii (Osnovnogo Zakona) RSFSR» [Law of the RSFSR of 27 December 1958 'On Amendments to Articles 14 and 31 of the Constitution (Framework Law) of the RSFSR']. Available at: http://constitution.garant.ru/history/ussr-rsfsr/1937/zakony/3946626/ (accessed: 20 February 2019). (In Rus.)

Zakon SSSR ot 11 fevralya 1957 g. «Ob utverzhdenii Ukazov Prezidiuma Verkhovnogo Soveta SSSR o vosstanovlenii natsional'noy avtonomii balkarskogo, chechenskogo, ingushskogo, kalmytskogo i karachaevskogo narodov» [Law of the USSR of 11 February 1957 'On Confirmation of Edicts Issued by the Presidium of the Supreme Council of the USSR and Declaring the Restoration of National Autonomies of the Balkar, Chechen, Ingush, Kalmyk and Karachay Peoples']. Vedomosti Verkhovnogo Soveta SSSR. 1957. No. 4. Art. 78. (In Rus.)

Zakon SSSR ot 11 fevralya 1957 g. «Ob otnesenii k vedeniyu soyuznykh respublik razresheniya voprosov oblastnogo, kraevogo administrativnoterritorial'nogo ustroystva» [Law of the USSR of 11 February 1957 'On Designation of Issues Pertaining to Oblast and Krai Administrative Divisions As Ones Under the Jurisdiction of Union Republics']. Vedomosti Verkhovnogo Soveta SSSR. 1957. No. 4. Art. 80. (In Rus.)

Zakon SSSR ot 25 dekabrya 1958 g. "Ob utverzhdenii Ukazov Prezidiuma Verkhovnogo Soveta SSSR "O pereimenovanii Buryat-Mongol'skoy Avtonomnoy Sovetskoy Sotsialisticheskoy Respubliki” $i$ "O preobrazovanii Kalmytskoy avtonomnoy oblasti v Kalmytskuyu Avtonomnuyu Sovetskuyu Sotsialisticheskuyu Respubliku” i o vnesenii izmeneniy v stat'yu 22 Konstitutsii (Osnovnogo Zakona) SSSR» [Law of the USSR of 25 December 1958 'On Confirmation of Edicts Issued by the Presidium of the Supreme Council of the USSR 'On Renaming of the Buryat-Mongolian Autonomous Soviet Socialist Republic' and 'On Transformation of Kalmyk Autonomous Oblast into the Kalmyk Autonomous Soviet Socialist Republic' and on Amendments to Article 22 of the Constitution (Framework Law) 
of the USSR']. Vedomosti Verkhovnogo Soveta SSSR. 1959. No. 1. Art. 18. (In Rus.)

Konstitutsii i konstitutsionnye akty RSFSR. 1918-1937 gg. [Constitutions and constitutional acts of the RSFSR: 1918 - 1937]. Coll. documents. Acad. A. Ya. Vyshinsky (ed.). USSR Acad. of Sc, Inst. of Law. Moscow: Vedomosti Verkhovnogo Soveta SSSR, 1940. Pp. 211-213. (In Rus.)

Kniga pamyati ssylki kalmytskogo naroda [A Memorial Book of the Kalmyk People]. Vol. 1, book 3: Restoration of autonomy and rehabilitation of the Kalmyk people. Part 1 'Restoration of autonomy (1956-1963)'. Coll. documents and materials. K. N. Ilyumzhinov et al. (eds.); V. Z. Atueva et al. (comps.). Elista: Kalm. Book Publ., 2004. 586 p. (In Rus.)

Postanovlenie Verkhovnogo Soveta SSSR ot 7 marta 1991 g. № 2013-1 «Ob otmene zakonodatel'nykh aktov v svyazi s Deklaratsiey Verkhovnogo Soveta SSSR ot 14 noyabrya 1989 goda "O priznanii nezakonnymi i prestupnymi repressivnykh aktov protiv narodov, podvergshikhsya nasil'stvennomu pereseleniyu, i obespechenii ikh prav"” [Decree of the Supreme Council of the USSR of 7 March 1991 No. 2013-1 'On Abrogation of Some Legislative Acts Subsequent to the Declaration of the Supreme Council of the USSR of 14 November 1989 'On Condemnation of Repressive Actions against Forcibly Deported Peoples as Essentially Illegal and Protection of Their Rights"']. Vedomosti S"ezda narodnykh deputatov SSSR $i$ Verkhovnogo Soveta SSSR. 1991. No. 11. Art. 302. (In Rus.)

Postanovlenie Soveta Natsional'nostey Verkhovnogo Soveta SSSR «Ob obrazovanii Ekonomicheskoy komissii Soveta Natsional'nostey» 11 fevralya $1957 \mathrm{~g}$. [Decree of the Nationalities Council of the Supreme Council of the USSR 'On Establishment of the Economic Commission under the Nationalities Council']. Vedomosti Verkhovnogo Soveta SSSR. 1957. No. 4. Art. 89. (In Rus.)

Reabilitatsiya: kak eto bylo. Dokumenty Prezidiuma TsK KPSS $i$ drugie materialy [The Rehabilitation: such as it was. Documents issued by the Presidium of the CPSU's Central Committee and other materials]. Vol. II. February 1956 - early 1980s. Artizov A. N. et al. (comps.). Moscow: MFD, 2003. 960 p. (In Rus.)

RSFSR. Zakony i postanovleniya. Khronologicheskoe sobranie zakonov, ukazov Prezidiuma Verkhovnogo Soveta i postanovleniy Pravitel'stva RSFSR, 1958-1960 [The RSFSR: laws and decrees. Coll. laws and decrees of the Presidium of the Supreme Council and government decrees of the RSFSR: 1958-1960]. M. A. Kopylovskaya (ed.); V. A. Boldyrev et al. (comps.). In 7 vols. Vol. 7: 1958-1960. Moscow: Gosyurizdat, 1960. 671 p. (In Rus.) Sovetskie konstitutsii [Constitutions of the Soviets]. Chrestomathy: in 4 vols. Vol. 3. USSR: 1936-1977. D. V. Kuznetsov (comp.). Blagoveshchensk: Blagoveshchensk State Pedagogical Univ., 2015. 18 p. (In Rus.) 


\section{References}

Azovkin I. A., Iezuitov V. M. Pending issues regarding the legal status of Autonomous Oblasts. Sovetskoe gosudarstvo i pravo. 1959. No. 5. Pp. 69-78. (In Rus.)

Anisimova T. B. Developing the constitutional legislation of the RSFSR: a national-state structure of the republic. Konstitutsionnye osnovy natsional'nogosudarstvennogo stroitel'stva SSSR. Coll. papers. Moscow: Acad. of Soc. Sc., Central Committee of CPSU, 1983. 131 p. (In Rus.)

Belousov S. S. Administrative and territorial changes in the Lower Volga Region during the Great Patriotic War and their consequences. Narody Yuga Rossii v otechestvennykh voynakh. Conf. proc. (6-7 September 2012, Rostov-on-Don). Akad. G. G. Matishov (ed.). Rostov-on-Don: South. Scient. Center of RAS, 2012. Pp. 290-295. (In Rus.)

Belousov S. S. National-territorial entities of the Kalmyk people in the $19^{\text {th }}-$ early-to-mid $20^{\text {th }}$ cc.: a role of the ethnic factor in the formation of administrative borders. Mezhetnicheskiy i mezhkonfessional'nyy dialog kak konsolidiruyuschaya osnova obschestva $v$ bor'be protiv global'nykh ugroz terrorizma i ekstremizma. Conf. proc. (Astrakhan, 10 October 2013). A. V. Syzranov, O. S. Popova (comps., eds.). Astrakhan: Sorokin R. V., 2013. Pp. 102-110. (In Rus.)

Zaparivannyi R. I. Vosstanovlenie natsional'noy avtonomii kalmytskogo naroda 1953-1958 gg. [Restoration of the Kalmyk people's autonomy: 19531958]. A PhD thesis. Astrakhan State Univ. Astrakhan, 2006. 22 p. (In Rus.)

Zaparivannyi R. I. Establishment of Kalmyk Autonomous Oblast within Stavropol Krai. Vklad narodov Severnogo Kavkaza v pobedu nad fashizmom $v$ Velikoy Otechestvennoy voyne 1941-1945 gg. Conf. proc. (27-28 April 2005). Ubushaev V. B. et al. (eds.). Elista: Kalmyk State Univ., 2005. Pp. 191-192. (In Rus.)

Zaparivannyi R. I. Transformation of Kalmyk Autonomous Oblast into a national republic: 1957-1958. Gumanitarnye issledovaniya. 2011. No. 1. Pp. 229-232. (In Rus.)

Zlatopolski D. L. Gosudarstvennoe ustroystvo SSSR [State structure of the USSR]. Moscow: Gosyurizdat, 1960. 300 p. (In Rus.)

Ilyumzhinov K. N., Maksimov K. N. Na puti $k$ demokratii [On the way towards democracy]. Elista: Dzhangar, 1998. 288 p. (In Rus.)

Istoriya Kalmykii s drevneyshikh vremen do nashikh dney [A history of Kalmykia from the earliest times to the present days]. In 3 vols. Vol. II. Elista: Gerel, 2009. (In Rus.)

Istoriya natsional'no-gosudarstvennogo stroitel'stva v SSSR [1917-1966 gg.] [A history of nation building in the USSR: 1917 to 1966]. D. A. Chugaev 
(ed.). USSR Acad. of Sc., Inst. of History. Moscow: Mysl', 1968-1970. In 2 vols. Vol. 2: Nation building in the USSR during the Socialist and Building-of-Communism eras (1937-1967). 1970. 276 p. (In Rus.)

Kim A. I. The state and legal status of the RSFSR revisited. Izvestiya vuzov. Pravovedenie. 1960. No. 1. Pp. 26-33. (In Rus.)

Kuprits N. Ya. The autonomous oblast as a form of Soviet autonomy and its legal status. Sovetskoe gosudarstvo i pravo. 1940. No. 5-6. Pp. 11-23. (In Rus.)

Maksimov K. N. Kalmykiya v sovetskuyu epokhu: politika i realii [Kalmykia during the Soviet era: policies and realia]. Elista: Gerel, 2013. 464 p. (In Rus.)

Maksimov K. N. From the Khrushchev Thaw to political rehabilitation of the Kalmyk people: restoration of the autonomy. Vestnik Kalmytskogo instituta gumanitarnykh issledovaniy RAN. 2017. Vol. 29. No. 1. Pp. 38-47. (In Rus.)

Semenov P. G. Autonomies in Soviet state building processes. Sovetskoe gosudarstvo i pravo. 1959. No. 3. Pp. 30-40. (In Rus.)

Sudavtsov N. D. Kalmykia within Stavropol Krai during the restoration of the Kalmyk people's autonomy (1957-1958 gg.). Vestnik Kalmytskogo instituta gumanitarnykh issledovaniy RAN. 2010. No. 2. Pp. 15-20. (In Rus.)

Tuguz Kh. I. Liquidation and restoration of the Kalmyk nationhood: political and legal aspects. Vestnik Adygeyskogo gosudarstvennogo universiteta. 2006. No. 4. Pp. 82-94. (In Rus.)

Ubushaev V. B., Ubushaev K. V. Kalmyki: vyselenie, vozvraschenie, vozrozhdenie. 1943-1959 gg. [The Kalmyks: deportation, return, revival (19431959)]. Russian Federal Agency for Education, Kalmyk State Univ. Elista: Kalmyk State Univ., 2007. 494 p. (In Rus.)

Ubushaev V. B., Ubushaev K. V. Kalmyks in the late 1950s: from an autonomous oblast to the republic. Vestnik Regional'nogo instituta innovatsionnykh issledovaniy. 2009. No. 1. Pp. 10-15. (In Rus.)

Ubushaev K. V. Vozrozhdenie natsional'noy avtonomii repressirovannogo naroda 1957-1958 gg. [Restoring the national autonomy of a repressed people: 1957 - 1958]. Russian Federal Ministry of Education and Science, Kalmyk State Univ. Elista: Kalm. State Univ., 2017. 118 p. (In Rus.)

Ubushaev K. V. Restoration of national autonomy of the Kalmyk people within the RSFSR. Vestnik Kalmytskogo universiteta. 2017. No. 1 (33). Pp. 68-73. (In Rus.)

Khalilov A. M. RSFSR - sotsialisticheskoe federativnoe gosudarstvo [The RSFSR - a federative socialist state]. Kazan: Kazan State Univ., 1967. 138 p. (In Rus.) 